\title{
Evaluation of a Complementary Cyber Education Program for a Pathophysiology Class
}

\author{
Ji-Soo Yoo', Sook-hee Ryue ${ }^{2}$, Jung Eun Lee ${ }^{1}$ and Jeong-Ah Ahn ${ }^{1}$ \\ ${ }^{1}$ College of Nursing and ${ }^{2}$ Department of Medical Education, College of Medicine, Yonsei University, \\ Seoul, Korea
}

Purpose: The goal of this study was to develop and evaluate a complementary cyber education program for a required pathophysiology class for nursing students.

Methods: The cyber education program comprised electronic bulletin boards, correspondence material storage, an announcement section, a report submission section, reference sites, and statistics on learning rates. Twelve online lectures complemented five lectures in the classroom. To evaluate the course's educational effectiveness, we performed an online objective questionnaire and an open questionnaire survey anonymously, and compared the complementary cyber education program with traditional classroom education.

Results: The complementary cyber education program effected significant improvements in scores for importance with regard to major, clarity of goals and education plans for courses, professor readiness, preciseness and description of lectures, amount and efficiency of assignments, and fairness in appraisal standards compared with the traditional classroom education group.

Conclusion: This study indicates that a complementary cyber education program provides nursing students with the flexibility of time and space, the newest information through updated lectures, efficient motivational aids through intimacy between the lecturer and students, and concrete and meaningful tasks. The complementary cyber education course also increased student effort toward studying and student satisfaction with the class.

Key Words: Distance education, Nursing education research

\section{INTRODUCTION}

Rapid advances in the information industry occur at new venues all around the world, and advances in information and communication give us new chances to use innovative resources in education. Because of this, conventional lectures are beginning to change along with the educational setting's advancement with the advent of cyber education [1]. In particular, distance education using the World Wide Web became a turning point in the departure from conventional classroom teaching [2] with new advanced media skills for delivering educational programs through the evolution of "e-learning" or "webbased learning." Web-based classes are prevalent in academic nursing programs, in programs for professional nursing development and also in other training programs at health care institutions.

Web-based learning offers a flexible, accessible and convenient learning experience for nursing students.
Received: July 27, 2009 - Accepted: November 11, 2009

Corresponding Author: Jeong-Ah Ahn

College of Nursing, Yonsei University, 262 Seongsanno, Seodaemun-gu, Seoul 120-752, Korea

TEL) 02-2228-3252 FAX) 02-392-5440 E-mail) narcii@hanmail.net
Korean J Med Educ 2009 Dec; 21(4): 365-371. doi: 10.3946/kjme.2009.21.4.365.

(C) The Korean Society of Medical Education. All rights reserved. 
Distance education provides students with a free meeting place and time in cyberspace, and induces them to learn positively and to search actively on their own. In fact, web-based cyber education is emerging as a new educational methodology. In order to meet these changes, web-based learning programs are developed and released $[3,4,5]$, and those programs are used in many universities these days. So studies demonstrating the educational efficiency of web-based learning programs are also needed continuously.

Particularly, Registered Nurse-Bachelor of Science in Nursing (RN-BSN) students work as hospital nurses and attend school at the same time. So web-based cyber education program would meet these students' needs to study using computers in a convenient place regardless of the time.

The purpose of this study was to develop and evaluate a complementary cyber education program in pathophysiology for the RN-BSN students in the College of Nursing.

\section{SUBJECTS AND METHODS}

\section{Cyber Education Operating Program}

The pathophysiology elective for RN-BSN students in the College of Nursing includes the subjects of anatomy and physiology, as well as the basic nursing sciences and their clinical applications. In February 2006, this course for RN-BSN college students was developed, including multimedia lecture materials such as PowerPoint (PPT; Microsoft, Redmond, USA) electronic files, and photographic (Camtasia Studio; TechSmith Co., Okemos, USA) and audio records (Breeze Presentation tool of PPT), for lecturing in conjunction with YSCEC (Yonsei Cyber Education Center, Seoul, Korea). From the second semester in 2006, the pathophysiology course was conducted for the first time as a cyber education program including online lectures to complement lectures in the classroom (blended learning).

The cyber education program was made up of an electronic bulletin board, a correspondence materials storage area, an announcements section (including information about the exams and assignments and a place for questions and answers), a report submission area, reference sites, and statistics on learning rates. (Fig. 1). This program included twelve online lectures and five lectures in the classroom. These classroom components were conducted as both lectures and discussion classes. For the cyber education program, lecturing and reference

Fig. 1. Cyber Education Homepage

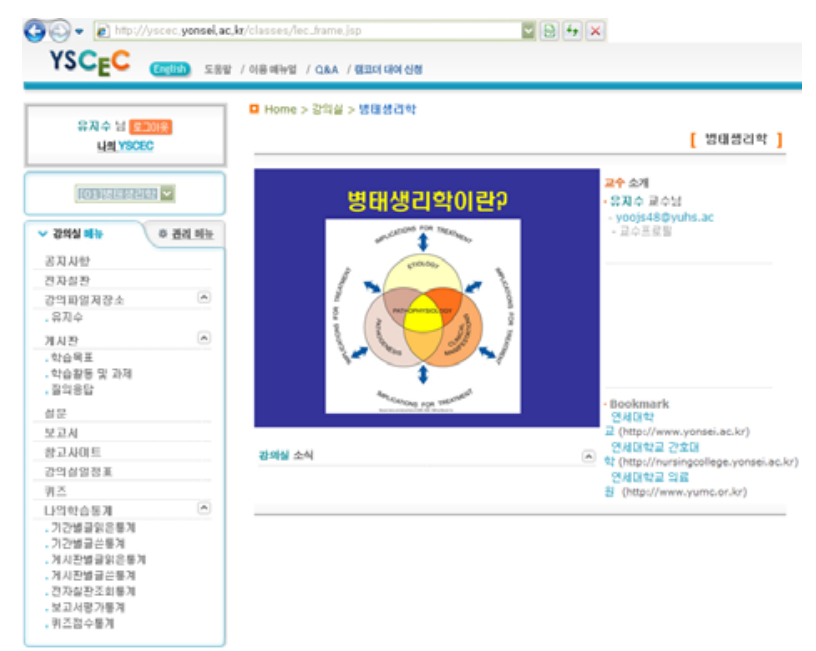

Fig. 2. Electronic Bulletin Board

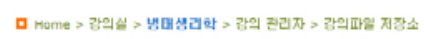

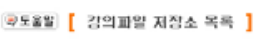

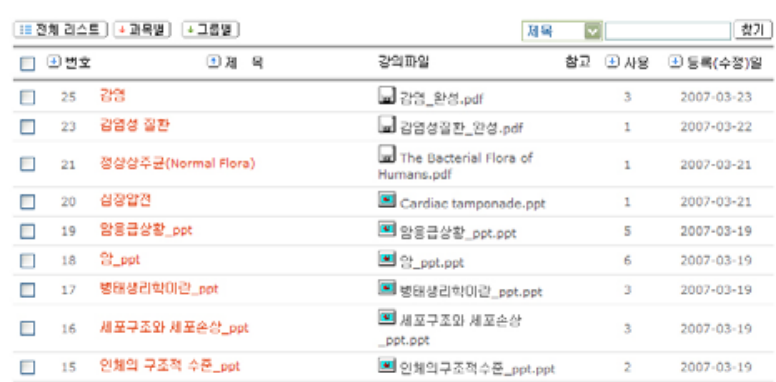


Fig. 3. Announcement Column

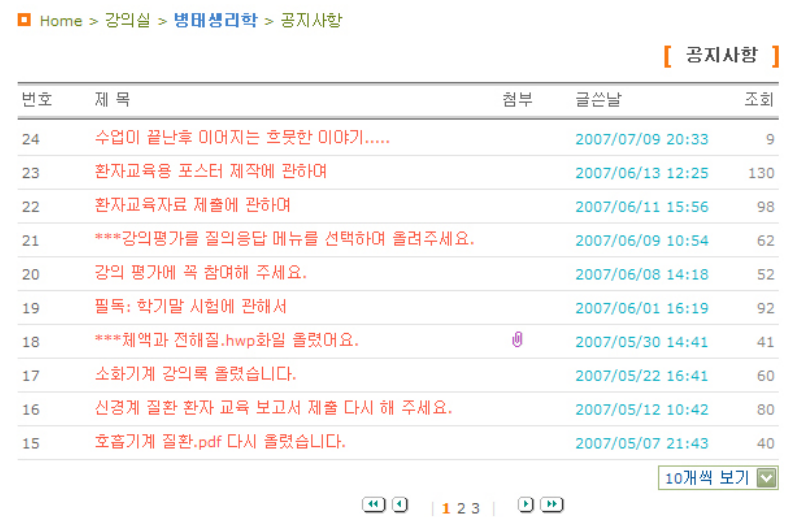

Fig. 4. Answers to Questions Column

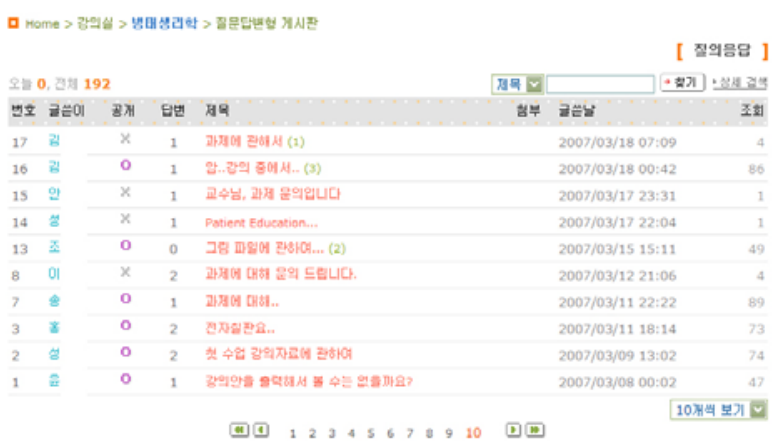

materials were available in Portable Document Format (PDF; Adobe Systems, San Jose, USA) or PPT files (Fig. 2). In the announcement column, there was a "notice" column and a "question and answer" (Q \& A) column. The lecturer gave students information about lecturing contents and how to use them in the notice column. In the Q \& A column, individual students could ask questions about lecturing contents and receive answers from the lecturer (Figs. 3, 4).

Students submitted patient education materials every week through the report column online, and the professor checked and marked their reports and promptly posted their individual grades (Fig. 5).

The administration menu was only accessible to the professor and the teaching assistant. This menu provided information about individual students' total number of electronic board accesses (reading and writing) and also
Fig. 5. Report Column

\begin{tabular}{|c|c|c|c|c|c|c|}
\hline \multicolumn{6}{|c|}{ 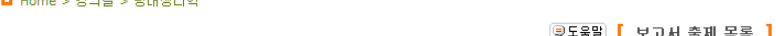 } & \\
\hline$\square$ & 번호 & 제 목 & 접수 & 제출기한 & 내상태 & 제출자 \\
\hline$\square$ & 7 & 소화기계 질환 환자교육보고서 1 & 마감훟접수중 & 2007-06-03 00:00 & 미제출 & $46 / 50$ \\
\hline$\square$ & 6 & 혈액계 질환 환자교육 보고서 1 & 마감후 접수중 & $2007-05-2600: 00$ & 미제출 & $46 / 50$ \\
\hline$\square$ & 5 & 신경계 질환 환자교윽 보고서 & 마감후 접수중 & $2007-05-1900: 00$ & 미제출 & $46 / 50$ \\
\hline$\square$ & 4 & 심혈관계 절환 환자 교육 봄 & 마감후 접수중 & $2007-05-1100: 00$ & 미제출 & $46 / 50$ \\
\hline$\square$ & 3 & 내분비계 절환 환자교윽 북 & 마감후접수중 & 2007-05-04 00:00 & 미제츌 & $46 / 50$ \\
\hline$\square$ & 2 & 호흡기 관련 절환 1 & 마감훟 접수중 & $2007-04-2700: 00$ & 미제출 & $46 / 50$ \\
\hline$\square$ & 1 & 유전관련 절환 ㅂ & 마감후 접수중 & $2007-04-0900: 00$ & 미제출 & $46 / 50$ \\
\hline
\end{tabular}

allowed the professor to enter the students' grades. Through this menu, the instructors could easily manage the lecturing program.

\section{Participants and Evaluation Methods}

46 students who attended the complementary cyber education program at the first semester in 2007 and 75 students who attended traditional classroom education at the first semester in 2006 completed online anonymous survey to determine the students' viewpoints and the educational efficiency of the course at each end of the semester. Students of both group learned the pathophysiology elective from the same professor, but different teaching methods were applied to them. Professor guaranteed students that online anonymous survey would not affect their grades before participation. The response rate was about $96 \%$ and $91 \%$, respectively.

The contents of survey as objective items, those were same to the both group students, included the importance of the course related to the student's major, the clarity of goals and the education plan for the course, professor readiness, the preciseness and description of lectures, the efficiency of assignments, and the fairness in appraisal standards. To identify strong or weak points of the complementary cyber education program, open subjective question items were added to the students of the complementary cyber education group. Objective items, which included a five-point Likert-type scale questionnaire and an open subjective questionnaire were answered 
anonymously through the online portal site of our university.

Statistical analyses of objective data were performed using the SPSS 12.0 statistical program (SPSS Inc., Chicago, USA). And Subjective data was analysed using the content analysis method. An initial pool of 194 items was derived from the answers of subjective questions. These initial items were reviewed for relevance and clarity by 4 researchers ( 2 students with a master's degree, 1 professor of nursing school, and 1 professor of medical school) and reduced to a set of 81 items. This 81 -item was then reviewed item-by-item by the process of discussion and agreement of researchers. Further revisions resulted in 58 items (48 strengths and 10 weaknesses).

\section{RESULTS}

\section{Characteristics of Participants}

Students were all in the fourth year of the College of Nursing. The average age of the participants was 29 years at each group.

\section{Comparison between Complementary Cyber Education and Traditional Class- room Education}

In the objective questionnaire survey, there were significant improvements in the scores (4.5 4.84) for importance with regard to major, clarity of goals,

Table 1. Comparison of Evaluations between the Complementary Cyber Education Group and the Traditional Classroom Education Group

\begin{tabular}{|c|c|c|c|c|}
\hline \multirow[t]{2}{*}{ Evaluation items } & $\begin{array}{l}\text { Complementary cyber } \\
\text { education group }(n=44)\end{array}$ & $\begin{array}{l}\text { Traditional classroom } \\
\text { education group }(\mathrm{n}=69 \text { ) }\end{array}$ & \multirow[t]{2}{*}{$\mathrm{t}$} & \multirow[t]{2}{*}{$\mathrm{p}$-value } \\
\hline & Mean $( \pm$ SD) & Mean $( \pm$ SD) & & \\
\hline Importance with regard to major & $4.7 \quad( \pm 0.59)$ & $4.36( \pm 0.64)$ & -2.85 & $0.005^{a l}$ \\
\hline Clarity of goals and education plan for courses & $4.84( \pm 0.43)$ & $3.92( \pm 0.93)$ & -7.08 & $0.001^{\text {al }}$ \\
\hline Professor readiness & $4.84( \pm 0.43)$ & $3.81( \pm 0.93)$ & -7.98 & $0.001^{a 1}$ \\
\hline Preciseness and description of lectures & $4.5 \quad( \pm 0.82)$ & $3.75( \pm 0.88)$ & -4.51 & $0.001^{a l}$ \\
\hline Amount and efficiency of assignments & $4.65( \pm 0.68)$ & $3.85( \pm 0.90)$ & -5.09 & $0.001^{\text {al }}$ \\
\hline Fairness in appraisal standards & $4.77( \pm 0.52)$ & $3.69( \pm 0.85)$ & -8.37 & $0.001^{a l}$ \\
\hline
\end{tabular}

SD: Standard deviation.

${ }^{a)} \leq 0.005$.

Table 2. Strengths of Complementary Cyber Education

\begin{tabular}{cll}
\hline \multicolumn{1}{c}{ Main topic } & \multicolumn{1}{c}{ Response example } \\
\hline Strengths & Self-learning abilities & Increasing study efficiency through visual images and animations \\
& & Using available individual study opportunities \\
Improving problem-solving skills \\
& Improving students' ability to use disease references \\
& Self-control of study time \\
Convenience & Convenient selection of study place \\
& Receiving prompt feedback on questions \\
& Facilitating easy consultation between professor and students at any timethe internet \\
Ouality of lectures & Participating in active communication between the professor and students \\
& Acquiring rich information about the exams and assignments \\
\hline
\end{tabular}


Table 3. Weaknesses of Complementary Cyber Education

\begin{tabular}{lll}
\hline \multicolumn{1}{c}{ Main topic } & \multicolumn{1}{c}{ Response example } \\
\hline Weaknesses & Contents of lectures & Enormous amount of lecture content \\
& Lack of consistency in the amount of lecture material each week \\
& Difficulty in classifying what is important and what points should be emphasized \\
& Difficulty in understanding some images in the learning materials \\
& Excessive range of exams and assignments \\
& Being interrupted by occasional background sounds (noises, ringing, etc.) \\
Technical problem & Decreased concentrationand study efficiency in cyber education \\
& Lack of individual responsibility for cumulative study and assignments \\
& Lack of instant feedback like that experienced in a traditional classroom \\
\hline
\end{tabular}

education plan for courses, professor readiness, preciseness and description of lectures, the amount and efficiency of the assignments, and fairness in appraisal standards when the complementary cyber education group was compared with the traditional classroom education group $(\mathrm{p} \leq 0.005)$. The results are shown in Table 1.

\section{Qualitative Evaluation on Complementary Cyber Education}

Main strengths and weaknesses of this complementary cyber education program from subjective questionnaire survey are shown in Tables 2 and 3.

The points identified as strengths as follows. The students mentioned self-learning abilities (an increase in study efficiency, the ability for individual study, an improvement in problem-solving skills, the ability to find references to diseases, and self-control of studying time), the convenience (the ease of use, very prompt feedback on questions, a more convenient selection of study location, and free consultation through the internet), and the quality of lectures (the rich information about the exams and assignments, and the active communication between professor and students).

For the weaknesses, students mentioned the contents of lectures (the enormous amount of lecture content, a lack of consistency in the amount of lecture material each week, difficulty in classifying what is important and what points to emphasize, difficulty in understanding the meaning of some images in the learning materials, and an excessive range of exams and assignments), technical problems (interruptions by occasional background sounds like noises and ringing), and the limitations of cyber education (decrease in concentration and study efficiency in cyber education, a lack of individual responsibility for cumulative study and assignments, and a lack of instant feedback like that experienced in a traditional classroom).

\section{DISCUSSION}

RN-BSN students in the college of nursing work in the hospital during daytime and take evening classes at school. For the students' convenience, a web-based cyber education program with a pathophysiology course using the personal computer was developed. The course provided students with flexible studying times and convenient accessibility, regardless of working time and place. The education program was constructed according to the suggestions of former studies so as to harmoniously combine cyber education classes and face-toface classes. This program had 12 cyber education classes and 5 face-to-face classes over a period of 12 weeks. 
According to the results based on learning efficiency, the complementary cyber education class had much higher satisfaction and preference among the students than the traditional classroom education class in terms of its importance with regard to major, clarity of goals and education plans for courses, professor readiness, preciseness and description of lectures, amount and efficiency of assignments, and fairness in appraisal standards. This result was different from those of some previous studies [6,7], which had asserted that cyber education classes with web-modules were not as efficient as traditional classroom education classes. They criticized the fact that web-based education cannot be tailored according to the learners' needs. However, some studies' results $[1,3,8,9]$ have found that the learning achievement of students studying through the internet was higher than that seen in traditional classes.

Previous studies have typically collected results from objective survey asking about course operating (teaching) method, quality or skill of the lecturer, quality of learning material, etc $[1,10,11,12]$. But this study included open subjective questions and tried to identify significant opinions and complementary points of the cyber education program.

While the existing cyber education classes presented one-way lectures, this program made students believe in their own abilities and possibilities through the online lecturer's positive and prompt feedback of their individual learning plans, reports and questions. Generally, cyberspace has been perceived as impersonal, but a personal relationship between the lecturer and students was reinforced through many reciprocal questions and answers in this program. The complementary cyber education program created a positive and open environment, and the students identified themselves as self-directed learners. Practically, RN-BSN students who had to work and study at the same time submitted good examples of patient education materials they had made. These gave students increased self-esteem as clinical nurses, elevated their academic achievements and improved their relationship with their patients. Consequently, the results suggest that this complementary cyber education program inspired its students to learn independently [13].

This study indicates that a complementary cyber education program provided nursing students with the flexibility of time and space, the newest information with updated lectures and efficient motivational aids [14] through intimacy between the lecturer and students including concrete and meaningful tasks. It also increased students' motivation to study, and gave them more satisfaction with the class. This study prompted us to reorganize the design of evaluation according to the objectives of cyber education [12].

The limitation of this study is that homogeneity between the complementary cyber education group and the traditional classroom education group was not verified properly.

\section{ACKNOWLEDGEMENTS}

This work was supported by the Yonsei University Research fund of 2007.

\section{REFERENCES}

1. Jang KS, Park OJ, Hong MS, Ryu S, Choi JY, Park SJ, Kim NY. A study on development of web-based learning program with multimedia ECG monitoring and it's application. J Korean Soc Med Inform 2003; 9: 101-110. 2. Kim HS, Kim IS, Cho WJ, Kim KS. The effects of internet based distance learning in nursing: focused on 
the RN-BSN program. J Korean Soc Med Inform 1997; 3: $147-152$.

3. Rosenlund C, Damask-Bembenek B, Hugie P, Matsumura G. The development of online courses for undergraduate nursing education. A faculty perspective. Nurs Health Care Perspect 1999; 20: 194-198.

4. Wills CE, Stommel M. Graduate nursing students' precourse and postcourse perceptions and preferences concerning completely web-based courses. J Nurs Educ 2002; 41: 193-201.

5. Kim HS, Kim IS, Cho WJ, Kim MI. The effects of internet-based distance learning in nursing. Comput Nurs 2000; 18: 19-25.

6. Ryan M, Carlton KH, Ali NS. Evaluation of traditional classroom teaching methods versus course delivery via the World Wide Web. J Nurs Educ 1999; 38: 272-277.

7. Yoo JS, Ham OK. Evaluation of internet-based distance learning in nursing education. J Korean Soc Med Inform 2001; 7: 39-46.

8. Jang HJ. The development and effectiveness of courseware for injection [dissertation]. [Seoul, Korea]:
Ewha Womans University; 1996.

9. Jeffries PR. Computer versus lecture: a comparison of two methods of teaching oral medication administration in a nursing skills laboratory. J Nurs Educ 2001; 40: 323-329.

10. Shin JS, Im MS, Kim SW. The effectiveness of online continuing medical education and learners' opinion about it. J Korean Soc Med Inform 2004; 10: 79-90.

11. Choi S, Kim S, Kim Y, Kwag W. The development of an e-learning based orientation program for new graduate nurses: the care on the oxygen therapy and suction. J Korean Soc Med Inform 2002; 8 Suppl 1: S164-167.

12. Lim SD, Lee J, ParK HS, Yu JR, Lee KY, Sohn IS, Lee R. Experience and consideration on online course evaluation by medical students. Korean J Med Educ 2008; 20: 367-371.

13. Lucas AF. Using psychological models to understand student motivation. New Directions for Teaching and Learning 1990; 42: 103-114.

14. Sass EJ. Motivation in the college classroom: what students tell us. Teach Psychol 1989; 16: 86-88. 